\title{
Diversity and dynamics of bacterial populations during spontaneous sorghum fermentations used to produce ting, a South African food
}

\author{
Evelyn Madoroba ${ }^{\mathrm{a}}$, Emma T. Steenkamp $^{\mathrm{b}, *}{ }$, Jacques Theron ${ }^{\mathrm{a}}$, Ilse Scheirlinck ${ }^{\mathrm{c}}$, \\ T. Eugene Cloete ${ }^{\mathrm{a}}$, Geert Huys ${ }^{\mathrm{c}}$ \\ a Department of Microbiology and Plant Pathology, University of Pretoria, Pretoria 0002, South Africa \\ ${ }^{\mathrm{b}}$ Forestry and Agricultural Biotechnology Institute, Department of Microbiology and Plant Pathology, University of Pretoria, Pretoria 0002, South Africa \\ c Laboratory for Microbiology, Faculty of Sciences, Ghent University, K. L. Ledeganckstraat 35, B-9000 Gent, Belgium
}

\section{A R T I C L E I N F O}

\section{Article history:}

Received 29 July 2010

\section{Keywords:}

Sorghum fermentation

Ting

Lactic acid bacteria

PCR-DGGE

pheS

\begin{abstract}
A B S T R A C T
Ting is a spontaneously fermented sorghum food that is popular for its sour taste and unique flavour. Insight of the microbial diversity and population dynamics during sorghum fermentations is an essential component of the development of starter cultures for commercial production of ting. In this study, bacterial populations associated with spontaneous sorghum fermentations were examined using a culture-independent strategy based on denaturing gradient gel electrophoresis and sequence analysis of V3-16S rRNA gene amplicons, and a culture-dependent strategy using conventional isolation based on culturing followed by $16 \mathrm{~S}$ rRNA and/or pheS gene sequence analysis. The entire fermentation process was monitored over a $54 \mathrm{~h}$ period and two phases were observed with respect to $\mathrm{pH}$ evolution and microbial succession. The first phase of the process ( $0-6 \mathrm{~h})$ was characterized by relatively high $\mathrm{pH}$ conditions and the presence of Enterococcus mundtii, albeit that this species was only detected with the culture-dependent approach. The second phase of the fermentation process (12-54 h) was characterized by increased acidity and the predominance of a broader range of lactic acid bacteria, including Lactococcus lactis, Lactobacillus fermentum, Lactobacillus plantarum, Lactobacillus rhamnosus, Weissella cibaria, Enterococcus faecalis, and a close relative of Lactobacillus curvatus, as well as some members of the Enterobacteriaceae family. The Lb. curvatus-like species was only detected with PCR-DGGE, while the majority of the other species was only detected using the culture-dependent approach. These findings highlighted the fact that a combination of both approaches was essential in revealing the microbial diversity and dynamics during spontaneous sorghum fermentations.
\end{abstract}

(c) 2011 Published by Elsevier GmbH.

\section{Introduction}

Sorghum is widely cultivated in arid and semi-arid regions of the world, and is considered to be the fifth most important cereal after wheat, maize, rice and barley [19]. However, sorghum as a main dietary constituent is usually associated with under-nourishment due to the lack of certain essential amino acids $[38,57]$ and the presence of anti-nutritional factors [31]. These shortcomings may be overcome by fermentation, which not only improves the nutritive value of the commodity, but also enhances its sensory properties $[4,11,32]$. As a result, various sorghum-based fermented foods with unique and appealing characteristics are produced wherever sorghum is cultivated. These include injera [23], kisra [51], ogi [2], mahewu [7], uji [48], muramba [52], bushera [53], togwa [46], and ting [6].

\footnotetext{
* Corresponding author. Tel.: +27 012 4204204; fax: +27 0124203266.

E-mail address: Emma.Steenkamp@up.ac.za (E.T. Steenkamp).
}

Ting is a sour porridge made by cooking fermented sorghum [6]. It is frequently used as a weaning food for infants in rural South Africa because it is inexpensive to prepare and does not require refrigeration or re-heating prior to consumption [43]. Due to its appetizing taste, adults also consume ting at major ceremonies such as weddings and funerals. In such traditional preparations, sorghum undergoes spontaneous and uncontrolled fermentation steered by microflora endogenous to the sorghum, as well as those associated with the preparation equipment and local environments. Consequently, conventional ting preparations vary greatly with respect to product quality, taste and acceptability [69]. Also, little is known about the microorganisms that participate in this fermentation. Although lactic acid bacteria [LAB] were previously isolated from fermented sorghum and identified as Lactobacillus plantarum, Lactobacillus fermentum and Lactobacillus rhamnosus [47], their involvement in the ting fermentation process and the possible role of other microbes remains to be determined. Such information is crucial for developing starter cultures that result in reduced fermentation time and ting with consistent microbiological and sensory qualities. 
To study the diversity and dynamics of microbial populations associated with specific fermented foods, a combination of culture-dependent and culture-independent approaches are typically applied. Culture-dependent approaches represent the only means of recovering microorganisms from the fermented substrate [50], although it is widely recognized that they do not allow analysis of true diversity and/or population dynamics $[3,49,58]$. On the other hand, various studies have shown that culture-independent approaches, such as denaturing gradient gel electrophoresis of $16 \mathrm{~S}$ rRNA gene amplicons (PCR-DGGE), provide a more reliable and reproducible means for studying microbial populations in complex food ecosystems $[9,16,65,75]$.

In this study, the diversity and dynamics of the microbial populations associated with the process of ting sorghum fermentation were investigated using a combination of culture-dependent and culture-independent methods. PCR-DGGE of the V3 region of the $16 \mathrm{~S}$ rRNA gene was used to monitor the succession of dominant microbial populations from the onset to the end of spontaneous sorghum fermentations. In parallel, conventional culturing and sequence-based approaches using the 16S rRNA and phenylalanyltRNA synthase ( $p h e S$ ) genes were employed to enumerate, isolate and identify the bacterial groups involved in these fermentations. This study is the first to investigate extensively the bacterial diversity and dynamics in the sorghum fermentation process, and is relevant for future development of appropriate and effective starter cultures.

\section{Materials and methods}

\section{Sorghum fermentations}

Fermentations were conducted at three different temperatures with sorghum flour obtained from two commercial sources in South Africa (i.e., King Food Corporation, Potchefstroom, and Nola Pvt Ltd., Randfontein). Individual sorghum slurries were prepared by mixing the respective sorghum flours thoroughly with sterile luke-warm $\left(\mathrm{ca} .40^{\circ} \mathrm{C}\right)$ distilled water $(1: 1[\mathrm{w} / \mathrm{v}])$ in sterile glass containers. The glass containers were then covered and incubated at 20, 25 and $30^{\circ} \mathrm{C}$ for $54 \mathrm{~h}$. These fermentations were undertaken over a period of six months (September 2004 to February 2005; one fermentation per month) and repeated during the following six months (March-August 2005). During the incubation period, $50 \mathrm{~mL}$ samples of the fermenting sorghum slurries were aseptically collected at the start of fermentation $(t=0 \mathrm{~h})$ and at 6 -h intervals until the end of fermentation $(t=54 \mathrm{~h})$. Each of the collected samples was divided into one $20 \mathrm{~mL}$ and two $15 \mathrm{~mL}$ aliquots, which were respectively used for culture-dependent analyses, $\mathrm{pH}$ determination with a Beckman model Ø 34 pH meter (Beckman Coulter, Fullerton, CA, USA), and immediately frozen and stored at $-20^{\circ} \mathrm{C}$ for later DNA extractions.

\section{Enumeration, isolation and primary phenotypic characterization of bacteria}

For culture-based enumeration and isolations, $10 \mathrm{~g}$ of the fermented sorghum were added to $90 \mathrm{~mL}$ of buffered peptone water $(0.1 \%[\mathrm{w} / \mathrm{v}]$ peptone, $0.85 \%[\mathrm{w} / \mathrm{v}] \mathrm{NaCl} ; \mathrm{pH} 7.2)$ and vortexed for 3 min to obtain homogenous mixtures. From these mixtures, 10fold dilutions were prepared in the same diluent and then surface inoculated onto the following selective media: MRS-5 [49] (Oxoid, Basingstoke, UK) for lactobacilli, M17 (Oxoid) for lactococci, ESA (Enterococcus selective agar; Merck, South Africa) for enterococci, violet red bile agar (VRBA, Oxoid) to obtain Gram-negative counts (GNC) and plate count agar (PCA, Oxoid) to obtain numbers of total aerobic bacteria. Plates were incubated at $30^{\circ} \mathrm{C}$ for $24-48 \mathrm{~h}$ for
MRS-5, M17 and ESA, $37^{\circ} \mathrm{C}$ for $24-48 \mathrm{~h}$ for VRBA, and $30^{\circ} \mathrm{C}$ for $72 \mathrm{~h}$ for PCA. For total aerobic and LAB counts, plates with between 30 and 300 colonies were selected for enumeration, while plates containing between 15 and 150 colonies, $>0.5 \mathrm{~mm}$ in diameter, were selected for determining GNC on VRBA. The counts were recorded as averages of three determinations and expressed as colony forming units (cfu) $\mathrm{g}^{-1}$.

Following incubation, colonies on the various growth media were grouped according to macroscopic and microscopic appearance. Representative colonies were then randomly picked and subcultured to obtain pure cultures, after which they were routinely grown in the appropriate broth media. LAB isolates were grown in MRS broth, while enterobacterial isolates were grown in nutrient broth using the incubation conditions described. All pure cultures were examined using light microscopy to score cell morphology, motility and Gram stain. Catalase and oxidase activity were tested using 3\% hydrogen peroxide and tetramethylp-phenylenediamine (TMPD), respectively [64]. Randomly selected isolates were also subjected to carbohydrate profile analysis using the API $50 \mathrm{CL}$ and API 20E systems (API Systems, bioMérieux, France). All cultures were stored at $-20^{\circ} \mathrm{C}$ in sterile Eppendorf tubes containing the appropriate broth media supplemented with $20 \%(\mathrm{v} / \mathrm{v})$ glycerol as a cryoprotectant.

\section{S rRNA and pheS sequence-based identification of pure cultures}

DNA was extracted from pure cultures using the Wizard ${ }^{\circledR}$ Genomic DNA Purification Kit (Promega, Madison, USA) or the method described by Pitcher et al. [62]. The 16S rRNA gene was amplified for each of the isolated pure cultures with the eubacterial universal primers 27F [44] and 1507R [34]. PCR mixtures con-

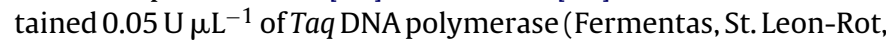
Germany) and PCR buffer containing $\mathrm{NH}_{2} \mathrm{SO}_{4}$ (Fermentas), $1.0 \mathrm{mM}$ $\mathrm{MgCl}_{2}, 0.2 \mathrm{mM}$ of each dNTP, $0.4 \mu \mathrm{M}$ of each primer, $1-2 \mathrm{ng} \mu \mathrm{L}^{-1}$ of template DNA and $8 \%(\mathrm{v} / \mathrm{v})$ dimethyl sulphoxide. The PCR cycling conditions consisted of denaturation at $95^{\circ} \mathrm{C}$ for $10 \mathrm{~min}$, followed by 35 cycles of denaturation at $94^{\circ} \mathrm{C}$ for $1 \mathrm{~min}$, annealing at $51^{\circ} \mathrm{C}$ for $30 \mathrm{~s}$, extension at $72^{\circ} \mathrm{C}$ for $1 \mathrm{~min}$, and a final extension for $10 \mathrm{~min}$ at $72{ }^{\circ} \mathrm{C}$. The resulting $16 \mathrm{~S}$ rRNA amplicons were sequenced with the original primers by Inqaba Biotech (Pretoria, South Africa). The pheS gene was amplified with primers PheS-21-F and PheS-23$\mathrm{R}$, as described by Naser et al. [56]. The resulting pheS amplicons were purified using the Nucleofast 96 PCR clean-up membrane system (Machery-Nagel, Germany) and sequenced using the original pheS PCR primers, the BigDye ${ }^{\circledR}$ Terminator v. 3.1 Cycle Sequencing kit (Applied Biosystems, USA) and an ABI PRISM ${ }^{\mathrm{TM}} 3100$ DNA sequencer (Applied Biosystems).

All raw sequence files were inspected and corrected, where necessary, using Chromas Lite 2.0 (Technelysium) and BioEdit v. 5.0.9 [28]. Sequences were compared to those in the nucleotide database of the National Centre for Biotechnology Information (NCBI; http://www.ncbi.nlm.nih.gov/) using blastn to obtain preliminary identifications for the isolated bacteria. To refine these identifications, the sequences generated in this study were subjected to phylogenetic analyses. For this purpose, 16S rRNA and pheS gene sequence alignments were generated using multiple sequence alignment based on Fast Fourier Transform (MAFFT v. 6) [37]. These alignments also included the sequence information for the relevant type strains of species in the genera Lactobacillus, Weissella, Lactococcus and Enterococcus, which were obtained from GenBank or from a taxonomic reference framework of phes consisting of sequences for Lactobacillus, Enterococcus, Lactococcus, Leuconostoc, Pediococcus and Weissella strains [70]. To determine the best-fit evolutionary models for the datasets, PAUP* v. 4.0b1 [72], together with Modeltest v. 3.7 [63], were used. The calculated parameters were then used to construct neighbor-joining $(\mathrm{NJ})$ 
Table 1

Average microbial counts ( $\mathrm{cfu} \mathrm{g}^{-1}$ ) at the start and end of spontaneous sorghum fermentations $\left(25^{\circ} \mathrm{C}\right)$ obtained on different selective media.

\begin{tabular}{|c|c|c|c|c|}
\hline \multirow[t]{2}{*}{ Isolation medium ${ }^{\mathrm{a}}$} & \multirow[t]{2}{*}{ Targeted groups } & \multirow[t]{2}{*}{ Time point } & \multicolumn{2}{|c|}{ Commercial sorghum flour ${ }^{\mathrm{b}}$} \\
\hline & & & K.F.C. & Nola \\
\hline VRBA & Gram-negative bacteria & $\begin{array}{l}t=0 \mathrm{~h} \\
t=54 \mathrm{~h}\end{array}$ & $\begin{array}{l}8.45 \times 10^{3} \\
9.0 \times 10^{6}\end{array}$ & $\begin{array}{l}8.3 \times 10^{3} \\
8.8 \times 10^{6}\end{array}$ \\
\hline ESA & Enterococci & $\begin{array}{l}t=0 \mathrm{~h} \\
t=54 \mathrm{~h}\end{array}$ & $\begin{array}{l}2 \times 10^{3} \\
3.62 \times 10^{8}\end{array}$ & $\begin{array}{l}1.8 \times 10^{3} \\
3.5 \times 10^{8}\end{array}$ \\
\hline MRS-5 & Lactobacilli & $\begin{array}{l}t=0 \mathrm{~h} \\
t=54 \mathrm{~h}\end{array}$ & $\begin{array}{l}9 \times 10^{3} \\
3.91 \times 10^{9}\end{array}$ & $\begin{array}{l}9.1 \times 10^{3} \\
3.89 \times 10^{9}\end{array}$ \\
\hline M17 & Lactococci & $\begin{array}{l}t=0 \mathrm{~h} \\
t=54 \mathrm{~h}\end{array}$ & $\begin{array}{l}3 \times 10^{3} \\
2.8 \times 10^{9}\end{array}$ & $\begin{array}{l}2.8 \times 10^{3} \\
2.92 \times 10^{9}\end{array}$ \\
\hline PCA & Aerobic bacteria & $\begin{array}{l}t=0 \mathrm{~h} \\
t=54 \mathrm{~h}\end{array}$ & $\begin{array}{l}1.9 \times 10^{5} \\
3.9 \times 10^{9}\end{array}$ & $\begin{array}{l}1.5 \times 10^{5} \\
2.3 \times 10^{9}\end{array}$ \\
\hline
\end{tabular}

a See text for information on suppliers of media.

b K.F.C. and Nola refer to commercial sorghum flour that was obtained from King Food Corporation and Nola Pvt Ltd., respectively.

distance-based [67] phylogenetic trees with PAUP*, and maximum likelihood (ML) trees with PhyML v. 2.4.3 [27]. Branch support was estimated with non-parametric bootstrap analysis based on 1000 replicates and the same parameters as before.

\section{PCR-DGGE}

In order to prepare high quality DNA for PCR-DGGE analyses, individual $15 \mathrm{~mL}$ samples were vortexed for $10 \mathrm{~min}$ in the presence of glass beads ( $2 \%$ [v/v], $150 \mu \mathrm{m}$-diameter beads; Sigma-Aldrich) and then centrifuged for $5 \mathrm{~min}$ at $1500 \times \mathrm{g}$ to remove the beads and remaining large sorghum particles. The bacterial cells in $1.5 \mathrm{~mL}$ of the individual supernatants were harvested by centrifugation at $5000 \times g$ for $15 \mathrm{~min}$. The pelleted cells were frozen at $-20^{\circ} \mathrm{C}$ for $2 \mathrm{~h}$ and washed with sterile distilled water, after which DNA was extracted using the Wizard ${ }^{\circledR}$ Genomic DNA Purification Kit.

For PCR-DGGE analysis, the V3 region of the bacterial 16S rRNA gene was amplified with primer 518R and primer F357-GC, which has a 40-base GC-clamp at its 5'-end [55]. PCR was performed as described previously [75] on a MyCycler ${ }^{\mathrm{TM}}$ thermal cycler (BioRad, Hercules, USA). The 16S rRNA V3 region was also amplified from 13 different bacterial reference strains, and the resulting amplicons were combined for use as a DGGE reference standard [75]. The reference standard comprised amplicons from Bacteroides fragilis (DSM 1396), Bacteroides thetaiotaomicron (LMG 11262), Weissella cibaria (LMG 17699), Enterococcus flavescens (LMG 13518T), E. solitarius (LMG 12890T), Leuconostoc fructosum (LMG 9498T), Bacillus subtilis (LMG 7135T), Clostridium butyricum (LMG 1212), Lb. rhamnosus (LMG 6400T), Bifidobacterium longum subsp. longum (LMG 13197T), Bifidobacterium bifidum (LMG 11041T), Bifidobacterium animalis subsp. lactis (LMG 18314T), and Bifidobacterium dentium (LMG 11045T). DGGE was performed according to the procedure described by Muyzer et al. [55] with slight modifications, as described previously [75]. All PCR-DGGE experiments were performed in duplicate. The inclusion of the reference standard on gels allowed for digital normalization and comparison of the fragment profiles on different DGGE gels by using BioNumerics v.4.0 [75].

\section{Sequence analysis of PCR-DGGE fragments}

To determine the likely taxonomic identity of the bacteria for which individual 16S rRNA V3 PCR-DGGE fragments were generated, the most intense fragments at each of the different fermentation sampling time points ( $t=0 \mathrm{~h}$ to $t=54 \mathrm{~h}$ ) were excised from DGGE gels. The gel slices were then incubated overnight at $4{ }^{\circ} \mathrm{C}$ in sterile distilled water [68], after which the eluted DNA was used as template to re-amplify the specific fragments using the same PCR and cycling conditions as described above. After confirming that the re-amplified fragments co-migrated with the expected 16S rRNA V3 PCR fragments of the original samples on DGGE gels, the re-amplified fragments were subjected to another round of PCR using primers $518 \mathrm{R}$ and $357 \mathrm{~F}$ to remove the GC-clamp from the amplicons. Primer $357 F$ is the same as primer F357-GC, except that is lacks the GC-clamp at its $5^{\prime}$-end [55]. The resulting products were then purified with the QIAquick PCR purification kit (QIAGEN, Germany) and sequenced using primers 518R and 357F, and the same procedure as described above for the pheS amplicons. The resulting raw sequence data were inspected and corrected where necessary and individual 16S rRNA V3 sequences were compared using blastn to those in the NCBI nucleotide database. By making use of BioEdit, the 16S rRNA V3 sequences were also compared to the complete 16S rRNA sequences obtained for the pure cultures.

\section{Results}

\section{Enumeration and primary characterization of bacteria}

Enumeration of total and specific groups of bacteria was carried out on five different types of media (PCA, MRS-5, M17, VRBA and ESA). However, these enumerations were performed for the fermentations at $25^{\circ} \mathrm{C}$ only, as similar PCR-DGGE profiles were obtained at all three fermentation temperatures (see below). Total bacterial counts were initially low, but increased considerably towards the end of the fermentation (Table 1). Although LAB were predominant on most media (except VRBA), none of the media were sufficiently specific to allow growth of only particular LAB species. For example, both Gram-positive cocci and rods were isolated indiscriminately from MRS-5, ESA and M17 media.

Based on macroscopic and microscopic observations, 192 isolates associated with the fermentation process using both sorghum sources were randomly selected. Of these, all Gram-positive, catalase-negative, non-motile and oxidase-negative isolates were considered presumptive LAB, and all Gram-negative, oxidasenegative and catalase-positive rods were considered presumptive Enterobacteriaceae. Carbohydrate fermentation profile comparisons further allowed a set of 32 isolates representative of the diversity of bacteria dominant at the beginning and end of the fermentation process to be selected. This set of 32 isolates was subsequently subjected to $16 \mathrm{~S}$ rRNA and pheS sequence-based identification (Table 2).

\section{S rRNA and pheS sequence-based identification of pure cultures}

Two separate 16S rRNA data sets were created to determine the possible identities of the isolates from this study (GenBank 

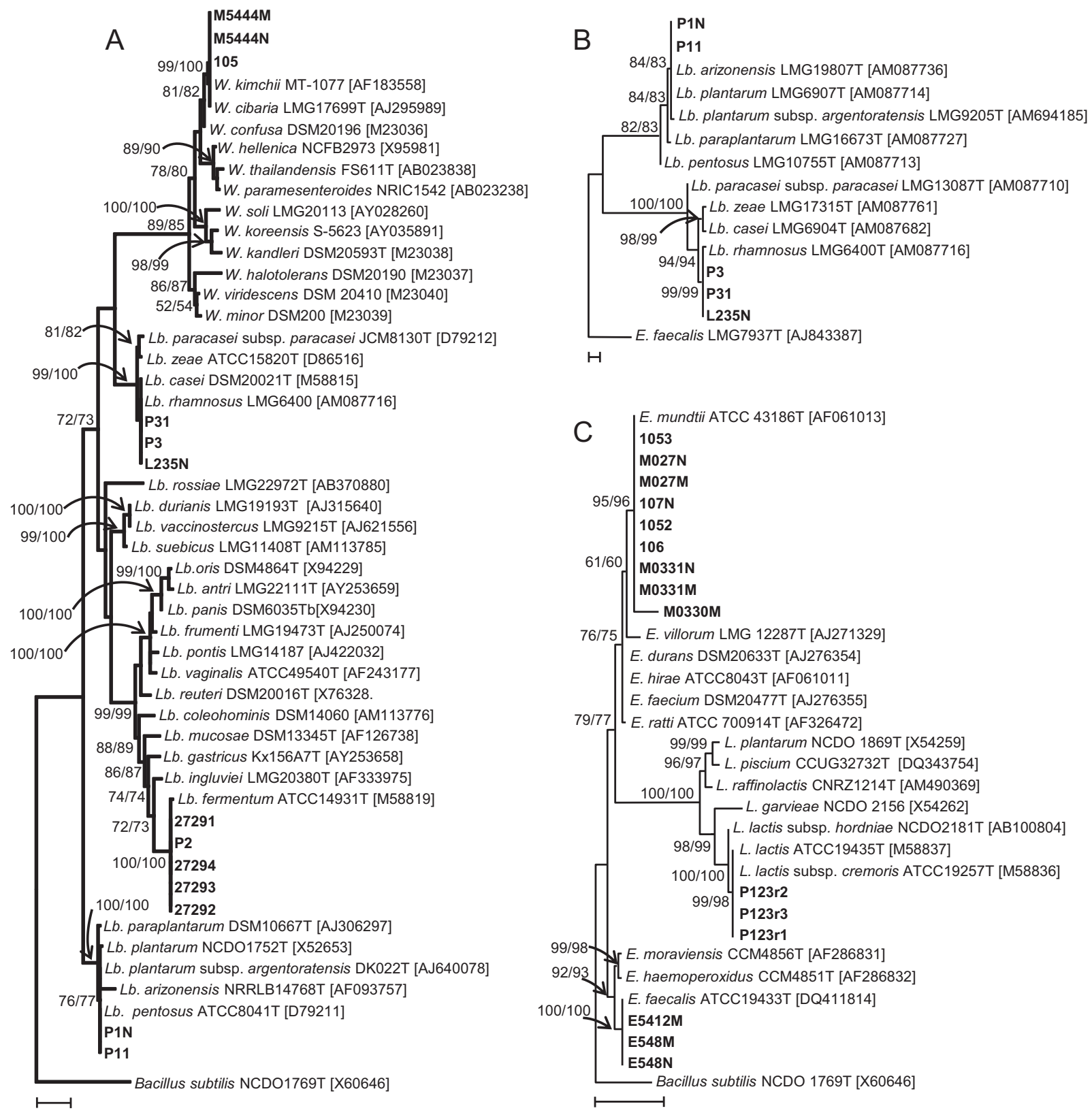

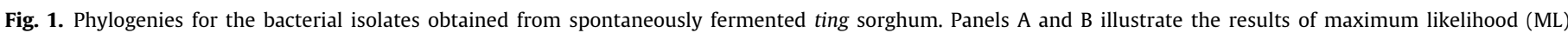

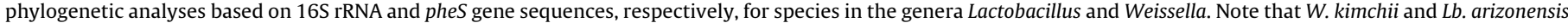

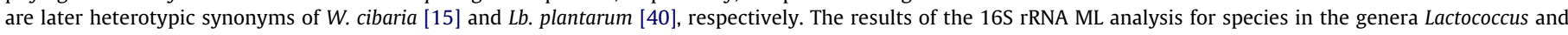

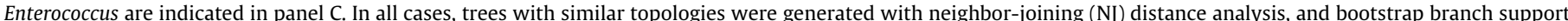

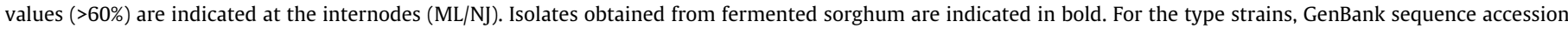

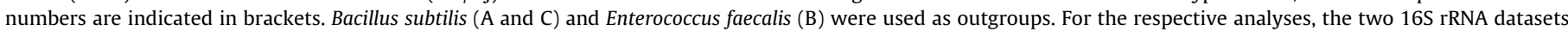

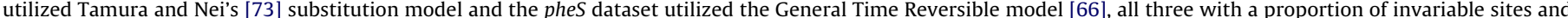
gamma correction for among site variation.

accession numbers GU372694-GU372721). One included 16S rRNA gene sequences for the putative Lactobacillus and Weissella species (i.e., the Gram-positive rod-shaped bacteria), while the other included putative Lactococcus and Enterococcus species (i.e., the Gram-positive coccoid bacteria). These alignments also included the full-length or near full-length 16S rRNA sequences for the type strains of the species in these genera that were obtained from GenBank. Within the Lactobacillus and Weissella phylogeny (Fig. 1A), isolates P11 and P1N formed part of a clade containing Lb. plantarum, Lactobacillus paraplantarum, Lactobacillus pentosus and Lactobacillus arizonensis, while P31, L235N and P3 were most closely related to $\mathrm{Lb}$. rhamnosus and Lactobacillus casei. The $16 \mathrm{~S}$ rRNA sequence similarities between the taxa within the two clades were respectively $>99.9 \%$. However, phylogenetic analysis based on aligned pheS sequences (Fig. 1B) allowed unambiguous assignment of isolates P11 and P1N to Lb. plantarum (>99.91\% pheS sequence similarity), and isolates $\mathrm{P} 31, \mathrm{~L} 235 \mathrm{~N}$ and $\mathrm{P} 3$ to $\mathrm{Lb}$. rhamnosus ( $>99.96 \%$ pheS sequence similarity) (GenBank accession numbers GU372722-GU372726). The 16S rRNA phylogeny (Fig. 1A) indicated that isolates 27291, 27292, 27293, 27294 and P2 probably represented $L b$. fermentum (99.99\% sequence similarity), and isolates M5444M, M5444N and 105 were most closely related to $W$. cibaria (99.99\% sequence similarity). Within the Lactococcus and Enterococcus phylogeny (Fig. 1C), isolates P123r1, P123r2, P123r3 grouped with Lactococcus lactis, isolates M027N, M027M, M0331M, M0331N, 107N, 106, 1052 and 1053 grouped with Enterococcus 
Table 2

Likely species identities of bacteria isolated at the beginning and end of sorghum fermentations.

\begin{tabular}{|c|c|c|c|}
\hline Isolate & Sorghum source ${ }^{\mathrm{a}}$ & Sampling time (h) & Identification $^{\mathrm{b}}$ \\
\hline M027M & K.F.C. & 0 & E. mundtii \\
\hline M027N & Nola & 0 & E. mundtii \\
\hline M0331M & K.F.C. & 0 & E. mundtii \\
\hline M0331N & Nola & 0 & E. mundtii \\
\hline M030M & K.F.C. & 0 & E. mundtii \\
\hline $107 \mathrm{~N}$ & Nola & 0 & E. mundtii \\
\hline 106 & K.F.C. & 0 & E. mundtii \\
\hline 1052 & Nola & 0 & E. mundtii \\
\hline 1053 & K.F.C. & 0 & E. mundtii \\
\hline E548M & K.F.C. & 54 & E. faecalis \\
\hline E548N & Nola & 54 & E. faecalis \\
\hline E5412M & K.F.C. & 54 & E. faecalis \\
\hline P11 & K.F.C. & 54 & Lb. plantarum \\
\hline P1N & Nola & 54 & Lb. plantarum \\
\hline P3 & K.F.C. & 54 & Lb. rhamnosus \\
\hline P31 & Nola & 54 & Lb. rhamnosus \\
\hline L235N & Nola & 54 & Lb. rhamnosus \\
\hline P2 & K.F.C. & 54 & Lb. fermentum \\
\hline 27291 & K.F.C. & 54 & Lb. fermentum \\
\hline 27292 & Nola & 54 & Lb. fermentum \\
\hline 27293 & Nola & 54 & Lb. fermentum \\
\hline 27294 & Nola & 54 & Lb. fermentum \\
\hline M5444M & K.F.C. & 54 & W. cibaria \\
\hline M5444N & Nola & 54 & W. cibaria \\
\hline 105 & K.F.C. & 54 & W. cibaria \\
\hline P123r1 & K.F.C. & 54 & L. lactis \\
\hline P123r2 & Nola & 54 & L. lactis \\
\hline P123r3 & Nola & 54 & L. lactis \\
\hline V5422M & K.F.C. & 54 & Enterobacteriaceae \\
\hline V5423N & Nola & 54 & Enterobacteriaceae \\
\hline V5430 & Nola & 54 & Enterobacteriaceae \\
\hline V5431 & K.F.C. & 54 & Enterobacteriaceae \\
\hline
\end{tabular}

a Sorghum source refers to the commercial company that produced the sorghum flour (K.F.C. for King Food Corporation and Nola for Nola Pvt Ltd.).

b Identification obtained with sequence analysis of 16S rRNA and pheS genes (Fig. 1).

mundtii, and isolates E548N, E5412M and E548M clustered with Enterococcus faecalis (in all cases with 16S rRNA sequence similarity values $>99.9 \%$ ).

\section{PCR-DGGE analysis}

The diversity and dynamics of microflora during spontaneous fermentation of sorghum flour were studied using PCR-DGGE of the ca. 250-bp V3 hypervariable region of the 16S rRNA gene. Based on the PCR-DGGE profiles and pH of the growth medium, the overall fermentation process appeared to be characterized by two phases (Fig. 2). The first phase (0-6 h) was associated with a relatively small change in $\mathrm{pH}$ (6.64-6.0) and DGGE profiles showing extremely low complexity, mainly consisting of one intense fragment that was already present at $t=0 \mathrm{~h}$. The second phase $(12-54 \mathrm{~h})$ was characterized by a more complex DGGE pattern including 12 major fragments most of which remained present until the end of fermentation. During this phase of the fermentation, the $\mathrm{pH}$ also dropped from 5.69 to 3.79, after which it remained constant. Similar $\mathrm{pH}$ and PCR-DGGE profiles were obtained for the fermentations with both of the commercial sorghum flour brands included in this study. All duplicate samples generated identical PCR-DGGE profiles during the course of spontaneous fermentation, emphasizing the reproducibility of this method throughout the study. Likewise, similar $\mathrm{pH}$ and PCR-DGGE profiles were obtained for the fermentations conducted at 20,25 and $30^{\circ} \mathrm{C}$.

In order to assign species identities to the major PCR-DGGE fragments visualized during the fermentation process (Fig. 2), the V3-16S rRNA sequences from extracted and purified DGGE fragments were compared to full-length 16S rRNA gene sequences obtained for the pure cultures (Fig. 1). These analyses showed that DGGE fragments 10 and 12 probably corresponded with members of the LAB (i.e. L. lactis and W. cibaria) as their sequences were identical to those determined respectively for the isolates representing these species (see Fig. 1). Fragments 2-8 probably represented members of the Enterobacteriaceae genera Pantoea or Enterobacter, as their sequences displayed $\geq 98 \%$ similarity to the sequences obtained from GenBank for Pantoea spp. (e.g., Pantoea agglomerans; GenBank accession number AB571245) and Enterobacter sp. (Enterobacter sp. strain s172; GenBank accession number HM196843), as well as those for isolates V5422M, V5423N, V5430 and V5431. The sequence for PCR-DGGE fragment 11 did not match the full-length 16S rRNA gene sequences obtained for any of the pure cultures. According to the blastn results, this fragment shares $98 \%$ sequence similarity with that of the 16S rRNA sequence of Lactobacillus curvatus. Fragment 1 , the only one associated with the first fermentation stage (0-6 h), most likely represented the sorghum chloroplast $16 \mathrm{~S}$ rRNA gene based on its high sequence similarity (98\%) to that of the model monocotyledonous plant Zea mays.

Fragment 10 , assigned to $L$. lactis, appeared at $t=18 \mathrm{~h}$ and remained present until the end of fermentation in all experiments. Once it appeared, the relative intensity of this fragment remained constant or even increased throughout fermentation. In contrast, fragments representing other bacterial groups, especially those assigned to Enterobacteriaceae, decreased during the overall fermentation process.

\section{Bacterial diversity detected with culture-independent and culture-dependent approaches}

Table 3 shows a comparison of the bacterial diversity associated with spontaneous sorghum fermentations assessed using culture-independent and culture-dependent approaches. Overall, many bacterial groups in the ting samples remained undetected using PCR-DGGE. For example, E. mundtii was isolated at time $t=0 \mathrm{~h}$ (Table 2) but was not represented by a fragment in the DGGE profiles obtained from the corresponding sample. Also, culture-dependent approaches allowed isolation and identification

Table 3

Comparison of the bacterial diversity in ting sorghum fermentations at $25^{\circ} \mathrm{C}$ using culture-independent and culture-dependent approaches.

\begin{tabular}{|c|c|c|}
\hline Time of detection & Culture-independent approach ${ }^{\mathrm{a}}$ & Culture-dependent approach ${ }^{\mathrm{b}}$ \\
\hline$t=0 \mathrm{~h}$ & None & E. mundtii \\
\hline$t=54 \mathrm{~h}$ & $\begin{array}{l}\text { Lactococcus lactis } \\
\text { Weissella cibaria } \\
\text { Lactobacillus curvatus } \\
\text { Enterobacteriaceae (4 distinct sequences) }\end{array}$ & $\begin{array}{l}\text { L. lactis } \\
\text { W. cibaria } \\
\text { E. faecalis } \\
\text { Lb. plantarum } \\
\text { Lb. fermentum } \\
\text { Lb. rhamnosus } \\
\text { Enterobacteriaceae (4 isolates) }\end{array}$ \\
\hline
\end{tabular}

\footnotetext{
a Identifications are based on sequence analysis of the V3 region of the 16S rRNA gene after PCR-DGGE (Fig. 2).

b Identifications are based on the results of phylogenetic analyses using the 16S rRNA and pheS genes (Fig. 1).
} 


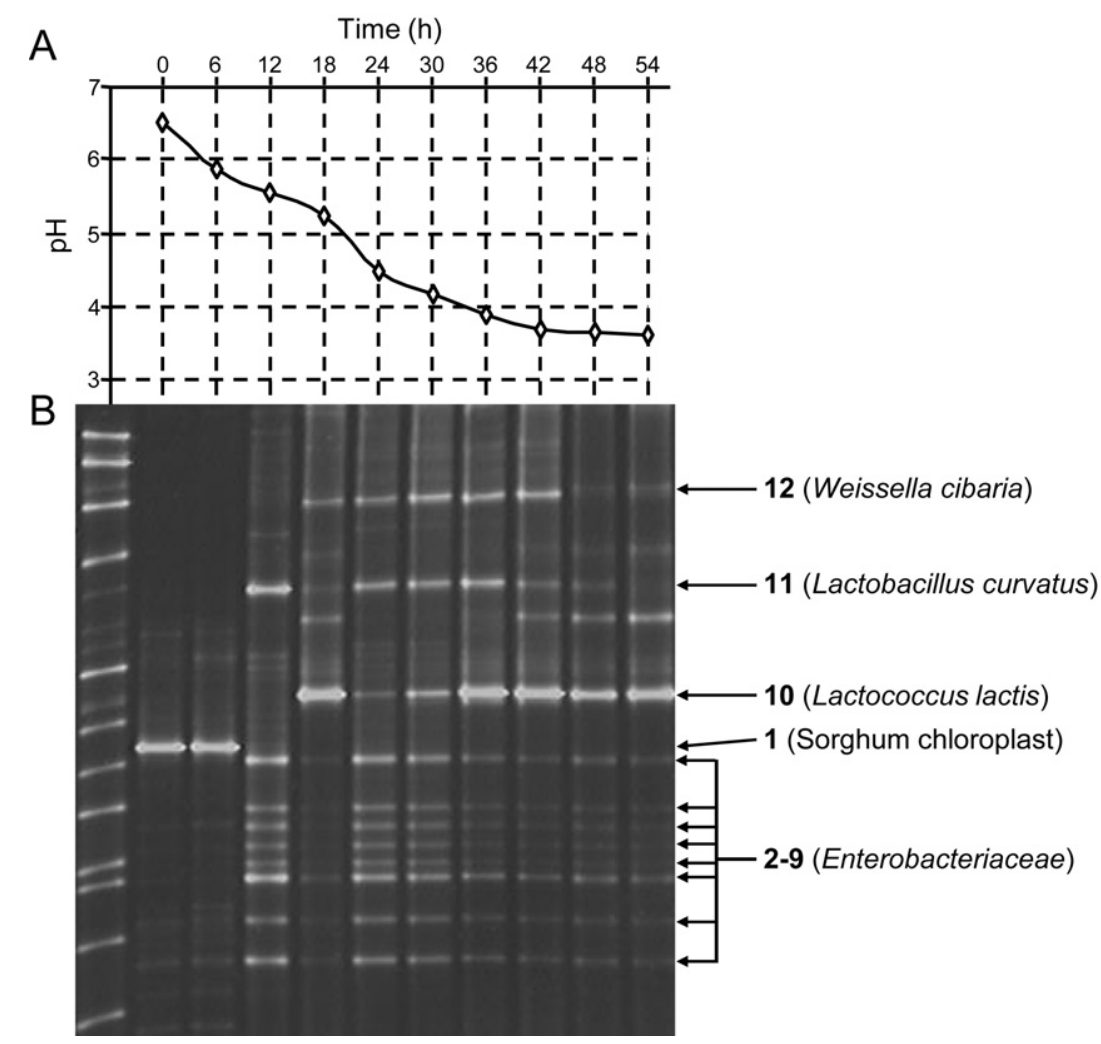

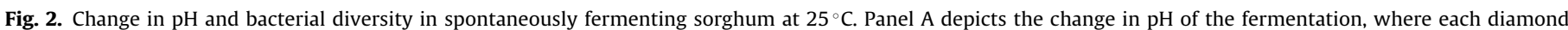

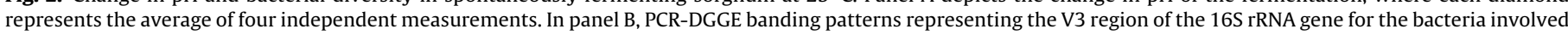

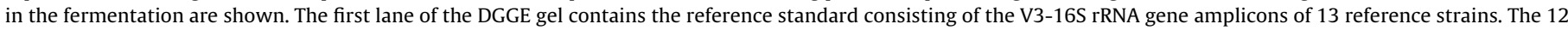

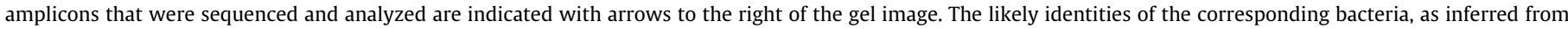
phylogenetic (Fig. 1) and blastn analyses, are indicated in brackets.

of $L b$. plantarum, Lb. rhamnosus and $L b$. fermentum at time $t=54 \mathrm{~h}$, whereas their corresponding V3-16S rRNA fragments were absent from the PCR-DGGE profiles at comparable time points (Table 3). On the other hand, an isolate presumably representing $L b$. curvatus, that was predominant in PCR-DGGE profiles at time points $t=42-54 \mathrm{~h}$, could not be isolated from the fermented samples despite numerous attempts.

\section{Discussion}

Spontaneous sorghum fermentations used in the preparation of ting were characterized by two distinct phases linked to changes in bacterial diversity and $\mathrm{pH}$. There was an apparent shift in microbial diversity from low-complexity PCR-DGGE profiles and relatively high $\mathrm{pH}$ to more complex PCR-DGGE profiles and increased acidity (Fig. 1). During the first phase, bacterial counts were very low $\left(<8.5 \times 10^{3} \mathrm{cfu} \mathrm{g}^{-1}\right.$, Table 1$)$ and thus below the detection limit of PCR-DGGE. The single intense DGGE fragment dominating the first fermentation phase represented the $\mathrm{V} 3$ region of the $16 \mathrm{~S}$ rRNA gene encoded on the sorghum chloroplast. In this respect, the finding of a chloroplast-derived amplicon is another example of the crossreactivity of $16 \mathrm{~S}$ rRNA gene-based PCR primers with eukaryotic DNA [36]. During the second phase, PCR-DGGE detected L. lactis which remained dominant until the end of the experiment. In addition, $W$. cibaria and the putatively identified $L b$. curvatus were also among the predominant species at the end of the fermentations. These results are in agreement with the generally accepted concept that traditional fermentations are dominated by a few microbial species that are selected during the course of fermentation as a result of physiological and metabolic adaptation to the food matrix $[29,35]$. The relative dominance of the homofermentative L. lactis over other bacteria may be due to its tolerance to low $\mathrm{pH}$, which may reduce growth of heterofermentative LAB [45]. Therefore, $L$. lactis can be considered as one of the most well-adapted organisms in sorghum fermentation processes. Provided that this observation is further substantiated by additional quantitative assessments, $L$. lactis strains thus may be used to control sorghum fermentations resulting in standardized ting products.

The $\mathrm{LAB}$ species associated with the production of ting have previously been implicated in the production of a range of fermented cereals with desirable sensory properties. $L$ b. plantarum has been isolated from fermented cereals such as ogi [61], mageu [33] and kunun zaki [22], while the heterofermentative $L b$. fermentum was previously isolated from mawe [35] and kenkey [30]. Isolates identified as ' $L b$. curvatus- $L b$. sake' were recovered from sorghumbased fermented weaning food [42]. Also, enterococci have been shown to form part of the microflora of certain cheeses and are responsible for sensory characteristics of the final product [20]. However, a number of bacterial taxa which are not commonly associated with food were also isolated from the spontaneously fermented sorghum. The majority of these are naturally associated with plants and are commonly found on plant-based material $[51,60]$. For example, the plant-associated E. mundtii [12] was isolated at the beginning of the process and has been reported as an environmental contaminant [9]. The same is also true for Enterobacteriaceae such as Pantoea species that generally represent plant endophytes [41], albeit that some Pantoea species are associated with human diseases [13].

One of the broadly recognized advantages of subjecting food materials to LAB-steered fermentation processes is the inhibitory effect this has on the growth of other microorganisms, especially food-borne pathogens [39,59]. Several previous studies have 
shown that the growth of members of the Enterobacteriaceae and other bacteria is inhibited by the lactic acid produced during fermentation $[1,60]$. Some strains of E. faecalis and E. faecium may also produce bacteriocins that are active against various food-borne pathogens [21], making them suitable candidates for controlling emerging pathogens during food fermentation [8]. However, despite the prevalence of enterococci in fermented sorghum and other food products [24,26], species such as E. faecalis and E. faecium have been associated with infection that pose challenges to food safety [10]. In the current study, the presence of bacteria representing Enterobacteriaceae such as Pantoea species and E. faecalis during the end of the fermentations might be due to acid resistance or the presence of microenvironments in the food matrix that support the growth of these bacteria [5,76]. Overall, however, the intensity of PCR-DGGE fragments corresponding to Enterobacteriaceae decreased as that of $L$. lactis increased (Fig. 2). It is therefore likely that the unfavourable environment created by this and the other LAB slowed down the growth of Enterococcus species and the Enterobacteriaceae as fermentation progressed.

The comparison of culture-independent and culture-dependent approaches used in this study highlights the limitations of each approach. Some species were not detected using culturebased methods, while others were not detected using cultureindependent methods. PCR-DGGE showed a significant increase in the putatively identified $L b$. curvatus numbers from time points $t=42-54 \mathrm{~h}$ of the fermentation process, but were not isolated from the food matrix. This may be due to it entering a viable but non-cultivable state, characterized by metabolically active cells that do not produce colonies on both selective and non-selective media [25], thus illustrating one of the main benefits of cultureindependent approaches over culture-dependent methods [25,54]. Overall, however, the use of culture-dependent methods allowed identification of a higher number of bacterial species from fermented sorghum than culture-independent methods (Table 3). PCR-DGGE did not allow the detection of E. faecalis, E. mundtii, $L b$. rhamnosus, $L b$. plantarum and $L b$. fermentum that were isolated on culture media at the end of fermentation. This was probably because the bacteria occurred in numbers below the detection limit of PCR-DGGE [54]. In addition, biases at the level of DNA extraction and PCR specificity and efficiency $[9,14,17]$ could also have played a role. The inability of PCR-DGGE to detect all the bacterial species associated with fermented sorghum was also observed for sourdough $[49,71]$ and whey cultures of water buffalo mozzarella [16]. PCR-DGGE results are also strongly influenced by the intraspecific heterogeneous nature of the 16S rRNA gene region targeted [18,74], which might be the case for putative Pantoea and Enterobacter spp. detected in this study (Fig. 2).

A previous culture-dependent investigation of the microbial diversity in fermented sorghum [47] revealed the presence of some of the species also found in the current study (i.e., Lb. rhamnosus, $L b$. fermentum and $L b$. plantarum). In the earlier study, however, species such as L. lactis previously remained undetected. In the current study, the addition of nutritional supplements to molten MRS medium [49] probably improved the chances of isolating this species. Likewise, the use of ESA and M17 agar improved the probability of recovering $E$. faecalis that was isolated at the end of fermentation in this study, but which could not be detected on MRS in the previous study. Accurate and efficient description of bacterial populations during sorghum fermentations was therefore strongly dependent on the combined application of culture-independent and culture-dependent approaches.

The production of ting from spontaneously fermented sorghum flour results in immense variation in the sensory characteristics and quality of ting, making it a daunting task to upgrade its status to commercial level. In this study, microbial population dynamics and diversity during sorghum fermentations were analyzed using a combination of culture-independent and culture-dependent methods in order to identify the dominant bacteria. This information will be used subsequently in the development of appropriate starter cultures that may result in ting with standardized sensory profiles (reflecting appearance, aroma, sourness and taste) and fermentation time. However, this will require an in-depth evaluation of the contribution of such potential starter cultures to the safety and acceptability of sensory characteristics of ting.

\section{Acknowledgements}

We are grateful to the National Research Foundation, South Africa and the Third World Organization of Women in Science for providing financial support. I. Scheirlinck was financially supported by the Flemish Institute for the Promotion of Innovation by Science and Technology in Flanders (IWT-Vlaanderen) within the framework of the SBO project 'New Strategy for the Development of Functional and Performant Starter Cultures for Foods in Function of Food Qualitomics'. The Fund for Scientific Research-Flanders (FWOVlaanderen) is acknowledged for the postdoctoral fellowship of G. Huys.

\section{References}

[1] Adams, M.R., Nicolaides, L. (1997) Review of the sensitivity of different pathogens to fermentation. Food Control 8, 227-239.

[2] Akingbala, J.O., Rooney, L.W., Faubion, J.M. (1981) A laboratory procedure for the preparation of ogi, a Nigerian fermented food. J. Food Sci. 46, 1523-1526.

[3] Ampe, F., ben Omar, N., Guyot, J.P. (1999) Culture-independent quantification of physiologically active microbial groups in fermented foods using rRNAtargeted oligonucleotide probes: application to pozol, a Mexican lactic acid fermented maize dough. J. Appl. Microbiol. 87, 31-140.

[4] Au, P.M., Fields, M.L. (1981) Nutritive quality of fermented sorghum. J. Food Sci. $46,652-654$.

[5] Ben Omar, N., Ampe, F. (2000) Microbial community dynamics during production of the Mexican fermented maize dough pozol. Appl. Environ. Microbiol. 66, 3664-3673.

[6] Boling, M.B., Eisener, N. (1982) Bogobe: sorghum porridge of Botswana. In: Mertin, J.V. (Ed.), Proceedings on the International Symposium on Sorghum Grain Quality, International Crops Research Institute for the Semi Arid Tropics, Patancheru, pp. 32-35.

[7] Bvochora, J.M., Reed, J.D., Read, J.S., Zvauya, R. (1999) Effect of fermentation processes on proanthocyanidins in sorghum during preparation of Mahewu, a non-alcoholic beverage. Process Biochem. 35, 21-25.

[8] Callewaert, R., Hugas, M., De Vuyst, L. (2000) Competitiveness and bacteriocin production of enterococci in the production of Spanish-style dry fermented sausages. Int. J. Food Microbiol. 57, 33-42.

[9] Camu, N., De Winter, T., Verbrugghe, K., Cleenwerck, I., Vandamme, P., Takrama, J.S., Vancanneyt, M., De Vuyst, L. (2007) Dynamics and biodiversity of populations of lactic acid bacteria involved in spontaneous heap fermentation of cocoa beans in Ghana. Appl. Environ. Microbiol. 73, 1809-1824.

[10] Carlos, A.R., Santos, J., Semedo-Lemsaddek, T., Barreto-Crespo, M.T., Tenreiro, R. (2009) Enterococci from artisanal dairy products show high levels of adaptability. Int. J. Food Microbiol. 129, 194-199.

[11] Chavan, U.D., Chavan, J.K., Kadam, S.S. (1988) Effect of fermentation on soluble proteins and in vitro protein digestibility of sorghum, green gram and sorghumgreen gram blends. J. Food Sci. 53, 1574-1575.

[12] Collins, M.D., Farrow, J.A.E., Jones, D. (1986) Enterococcus mundtii sp. nov. Int. J. Syst. Bacteriol. 36, 8-12.

[13] De Champs, C., Le Seaux, S., Dubost, J.J., Boisgard, S., Sauvezie, B., Sirot, J. (2000) Isolation of Pantoea agglomerans in two cases of septic monoarthritis after plant thorn and wood sliver injuries. J. Clin. Microbiol. 38, 460-461.

[14] De Vero, L., Gala, E., Gullo, M., Solieri, L., Landi, S., Giudici, P. (2006) Application of denaturing gradient gel electrophoresis (DGGE) analysis to evaluate acetic acid bacteria in traditional balsamic vinegar. Food Microbiol. 23, 809-813.

[15] Ennahar, S., Cai, Y. (2004) Genetic evidence that Weissella kimchii Choi et al. 2002 is a later heterotypic synonym of Weissella cibaria Björkroth et al. 2002. Int. J. Syst. Evol. Microbiol. 54, 463-465.

[16] Ercolini, D. (2004) PCR-DGGE fingerprinting: novel strategies for detection of microbes in food. J. Microbiol. Methods 56, 297-314.

[17] Ercolini, D., Mauriello, G., Blaiotta, G., Moschetti, G., Coppola, S. (2004) PCRDGGE fingerprints of microbial succession during a manufacture of traditional water buffalo mozzarella cheese. J. Appl. Microbiol. 96, 263.

[18] Fogel, G.B., Collins, C.R., Li, J., Brunk, C.F. (1999) Prokaryotic genome size and SSU rDNA copy number: estimation of microbial relative abundance from a mixed population. Microbiol. Ecol. 38, 93-113.

[19] Food and Agriculture Organization of the United Nations, 2006 FAOSTAT - FAO Statistical Databases, http://faostat.fao.org/. 
[20] Franz, C.M.A.P., Stiles, M.E., Schleifer, K.H., Holzapfel, W.H. (2003) Enterococci in foods-a conundrum for food safety. Int. J. Food Microbiol. 88, 105-122.

[21] Franz, C.M.A.P., van Belkum, M.J., Holzapfel, W.H., Abriouel, H., Gálvez, A. (2007) Diversity of enterococcal bacteriocins and their grouping into a new classification scheme. FEMS Microbiol. Rev. 31, 293-310.

[22] Gaffa, T., Gaffa, A.T. (2004) Microbial succession during 'kunun zaki' production with sorghum (Sorghum bicolor) grains. World J. Microbiol. Biotechnol. 20, 449-453.

[23] Gebrekidan, B., Gebrettiwat, B. (1982) Sorghum injera: preparation and quality parametersL. In: ICRISAT, Proceedings of International Symposium on Sorghum Grain Quality, Patancheru, India, pp. 55-56.

[24] Giraffa, G. (2002) Enterococci from foods. FEMS Microbiol. Rev. 26, 163-171.

[25] Giraffa, G., Neviani, E. (2001) DNA-based, culture-independent strategies for evaluating microbial communities in food-associated ecosystems. Int. J. Food Microbiol. 67, 19-34.

[26] Gomes, B.C., Esteves, C.T., Palazzo, I.C.V., Darini, A.L.C., Felis, G.E., Sechi, L.A., Franco, B.D.G.M., De Martinis, E.C.P. (2008) Prevalence and characterization of Enterococcus spp. isolated from Brazilian foods. Food Microbiol. 25, 668-675.

[27] Guindon, S., Gascuel, O. (2003) A simple, fast, and accurate algorithm to estimate large phylogenies by maximum likelihood. Syst. Biol. 52, 696-704.

[28] Hall, T.A. (1999) BioEdit: a user-friendly biological sequence alignment editor and analysis program for Windows 95/98/NT. Nucleic Acids Symp. Ser. 41 95-98.

[29] Halm, M., Osei-Yaw, A., Hayford, A., Kpodo, K.A., Amoa-Awua, W.K.A. (1996) Experiences with the use of starter culture in the fermentation of maize for 'kenkey' production in Ghana. World J. Microbiol. Biotechnol. 12, 531-536.

[30] Halm, M., Sørensen, L.A., Jakobsen, M. (1993) Microbiological and aromatic characteristics of fermented maize dough from kenkey production in Ghana. Int. J. Food Microbiol. 19, 135-143.

[31] Hamacker, B.R., Kirleis, A.W., Mertz, E.T., Axtell, J.D. (1986) Effect of cooking on the protein profiles and in vitro protein digestibility of sorghum and maize. J. Agric. Food Chem. 34, 647-649.

[32] Hassan, I.A.G., El Tinay, A.H. (1995) Effect of fermentation on tannin content and in-vitro protein and starch digestibilities of two sorghum cultivars. Food Chem. 53, 149-151.

[33] Hesseltine, C.W. (1979) Some important fermented foods in mid-Asia, the Middle-East and Africa. J. Am. Oil Chemists' Soc. 56, 367-374.

[34] Heyndrickx, M., Vaterin, L., Vandamme, P., Kersters, K., De Vos, P. (1996) Applicability of combined amplified ribosomal DNA restriction analysis (ARDRA) patterns in bacterial phylogeny and taxonomy. J. Microbiol. Methods 26, 247-259.

[35] Hounhouigan, D.J., Nout, M.J.R., Nago, C.M., Houben, J.H., Rombouts, F.M. (1993) Characterization and frequency distribution of species of lactic acid bacteria involved in the processing of mawé, a fermented maize dough from Bénin. Int. J. Food Microbiol. 18, 279-287.

[36] Huys, G., Vanhoutte, T., Joossens, M., Mahious, A.S., De Brandt, E., Vermeire, S. Swings, J. (2008) Coamplification of eukaryotic DNA with 16S rRNA gene-based PCR primers: possible consequences for population fingerprinting of complex microbial communities. Curr. Microbiol. 56, 553-557.

[37] Katoh, K., Kuma, K., Toh, H., Miyata, T. (2005) MAFFT version 5: improvement in accuracy of multiple sequence alignment. Nucleic Acids Res. 33, 511-518.

[38] Kazanas, N., Fields, M.L. (1981) Nutritional improvement of sorghum by fermentation. J. Food Sci. 46, 819-821.

[39] Kingamkono, R.R., Sjögren, E., Svanberg, U., Kaijser, B. (1995) Inhibition of different strains of enteropathogens in a lactic-fermenting cereal gruel. World J. Microbiol. Biotechnol. 11, 299-303.

[40] Kostinek, M., Pukall, R., Rooney, A.P., Schillinger, U., Hertel, C., Holzapfel, W.H., Franz, C.M.A.P. (2005) Lactobacillus arizonensis is a later heterotypic synonym of Lactobacillus plantarum. Int. J. Syst. Evol. Microbiol. 55, 2485-2489.

[41] Kuklinsky-Sobral, J., Araujo, W.L., Mendes, R., Geraldi, I.O., Pizzirani-Kleiner A.A., Azevedo, J.L. (2004) Isolation and characterization of soybean-associated bacteria and their potential for plant growth promotion. Environ. Microbiol. 6, 1244-1251.

[42] Kunene, N.F., Geornaras, I., von Holy, A., Hastings, J.W. (2000) Characterization and determination of origin of lactic acid bacteria from a sorghum-based fermented weaning food by analysis of soluble proteins and amplified fragment length polymorphism fingerprinting. Appl. Environ. Microbiol. 66, 1084-1092.

[43] Kunene, N.F., Hastings, J.W., von Holy, A. (1999) Bacterial populations associated with a sorghum-based fermented weaning cereal. Int. J. Food Microbiol. $49,75-83$.

[44] Lane, D.L. (1991) 16S/23S rRNA sequencing. In: Stackebrandt, E., Goodfellow, M. (Eds.), Nucleic Acid Techniques in Bacterial Systematics, Wiley, New York, pp. 115-175.

[45] Lin, C., Bolsen, K.K., Brent, B.E., Fung, D.Y.C. (1992) Epiphytic lactic acid bacteria succession during the pre-ensiling and ensiling periods of alfalfa and maize. J. Appl. Bacteriol. 73, 375-387.

[46] Lorri, W., Svanberg, U. (1995) An overview of the use of fermented foods for child feeding in Tanzania. Ecol. Food Nutr. 34, 65-81.

[47] Madoroba, E., Steenkamp, E.T., Theron, J., Huys, G., Scheirlinck, I., Cloete, T.E. (2009) Polyphasic taxonomic characterization of lactic acid bacteria isolated from spontaneous sorghum fermentations used to produce ting, a traditional South African food. Afr. J. Biotechnol. 8, 458-463.

[48] Mbugua, S.K. (1984) Isolation and characterization of lactic acid bacteria during the traditional fermentation of uji. East Afr. Agric. Forest. J. 50, 36-43.
[49] Meroth, C.B., Walter, J., Hertel, C., Brandt, M.J., Hammes, W.P. (2003) Monitoring the bacterial population dynamics in sourdough fermentation processes by using PCR-denaturing gradient gel electrophoresis. Appl. Environ. Microbiol. $69,475-482$

[50] Miambi, E., Guyot, J.P., Ampe, F. (2003) Identification, isolation and quantification of representative bacteria from fermented cassava dough using an integrated approach of culture-dependent and culture-independent methods. Int. J. Food Microbiol. 82, 111-120.

[51] Mohammed, S.I., Steenson, L.R., Kirleis, A.W. (1991) Isolation and characterization of miroorganisms associated with the traditional sorghum fermentation for production of Sudanese kisra. Appl. Environ. Microbiol. 57, 2529-2533.

[52] Mukuru, S. (1992) Traditional technologies in small grain processing. In: Gomez, M.R., House, L.R., Rooney, L.W., Dendy, D.A.V. (Eds.), Utilisation of Sorghum and Millets, International Crops Research Institute for Semi-arid Tropics, India, pp. 47-56.

[53] Muyanja, C.M.B.K., Narvhus, J.A., Treimo, J., Langsrud, T. (2003) Isolation, characterization and identification of lactic acid bacteria from bushera: a Ugandan traditional fermented beverage. Int. J. Food Microbiol. 80, 201-210.

[54] Muyzer, G., Smalla, K. (1998) Application of denaturing gradient gel electrophoresis (DGGE) and temperature gradient gel electrophoresis (TGGE) in microbial ecology. Antonie Leeuwenhoek 73, 127-141.

[55] Muyzer, G., De Waal, E.C., Uitterlinden, A.G. (1993) Profiling of complex microbial populations by denaturing gradient gel electrophoresis analysis of polymerase chain reaction-amplified genes coding for $16 \mathrm{~S}$ rRNA. Appl. Environ. Microbiol. 59, 695-700.

[56] Naser, S.M., Thompson, F.L., Hoste, B., Gevers, D., Dawyndt, P., Vancanneyt, M. Swings, J. (2005) Application of multilocus sequence analysis (MLSA) for rapid identification of Enterococcus species based on rpoA and pheS genes. Microbiology 151, 2141-2150.

[57] Neucere, N.J., Sumrell, G. (1979) Protein fractions from varieties of grain sorghum: amino acid composition and solubility properties. J. Agric. Food Chem. 27, 809-812.

[58] Nielsen, D.S., Teniola, O.D., Ban-Koffi, L., Owusu, M., Andersson, T.S., Holzapfel W.H.(2007) The microbiology of Ghanaian cocoa fermentations analysed using culture-dependent and culture-independent methods. Int. J. Food Microbiol. $114,168-186$.

[59] Nigatu, A., Gashe, B.A. (1994) Inhibition of spoilage and food-borne pathogens by lactic acid bacteria isolated from fermenting tef (Eragrostis tef) dough. Ethiop. Med. J. 32, 223-229.

[60] Nout, M.J.R. (1991) Ecology of accelerated natural lactic fermentation of sorghum-based infant-food formulas. Int. J. Food Microbiol. 12, 217-224.

[61] Odunfa, S.A., Adyele, S. (1985) Microbiological changes during the production of ogi-baba, a West-African fermented sorghum gruel. J. Cereal Sci. 3, 175-180.

[62] Pitcher, D.G., Saunders, N.A., Owen, R.J. (1989) Rapid extraction of bacterial genomic DNA with guanidium thiocyanate. Lett. Appl. Microbiol. 8, 151-156.

[63] Posada, D., Crandall, K.A. (1998) Modeltest: testing the model of DNA substitution. Bioinformatics 14, 817-818.

[64] Reddy, C.A., Beveridge, T.J., Breznak, J.A., Marzluf, G.A., Schmidt, T.M., Snyder L.R. 2007 Methods for General and Molecular Microbiology, 3rd ed., ASM Press, Washington, DC.

[65] Renouf, V., Claisse, O., Miot-Sertier, C., Lonvaud-Funel, A. (2006) Lactic acid bacteria evolution during wine making: use of $r p o B$ gene as target for PCR-DGGE analysis. Food Microbiol. 23, 136-145.

[66] Rodríguez, F., Oliver, J.L., Marín, A., Medina, J.R. (1990) The general stochastic model of nucleotide substitution. J. Theor. Biol. 142, 485-501.

[67] Saitou, N., Nei, M. (1987) Reconstructing phylogenetic trees. Mol. Biol. Evol. 4, 406-425.

[68] Sambrook, J., Fritsch, E.F., Maniatis, T. 1989 Molecular Cloning: A Laboratory Manual, 2nd ed., Cold Spring Harbor Laboratory Press, Cold Spring Harbor, NY.

[69] Sanni, A.I. (1993) The need for process optimization of African fermented foods and beverages. Int. J. Food Microbiol. 18, 85-95.

[70] Scheirlinck, I., Van der Meulen, R., Van Schoor, A., Vancanneyt, M., De Vuyst, L., Vandamme, P., Huys, G. (2007) Influence of geographical origin and flour type on diversity of lactic acid bacteria in traditional Belgian sourdoughs. Appl. Environ. Microbiol. 73, 6262-6269.

[71] Scheirlinck, I., Van der Meulen, R., Van Schoor, A., Vancanneyt, M., De Vuyst, L., Vandamme, P., Huys, G. (2008) Taxonomic structure and stability of the bacterial community in Belgian sourdough ecosystems as assessed by culture and population fingerprinting. Appl. Environ. Microbiol. 74, 2414-2423.

[72] Swofford, D.L. 2002 PAUP*. Phylogenetic Analysis Using Parsimony (* and other methods). Version 4, Sinauer Associates, Sunderland, MA

[73] Tamura, K., Nei, M. (1993) Estimation of the number of nucleotide substitutions in the control region of mitochondrial DNA in humans and chimpanzees. Mol. Biol. Evol. 10, 512-526.

[74] Ueda, K., Seki, T., Kudo, T., Yoshida, T., Kataoka, M. (1999) Two distinct mechanisms cause heterogeneity of $16 \mathrm{~S}$ rRNA. J. Bacteriol. 181, 78-82.

[75] Van der Meulen, R., Scheirlinck, I., Van Schoor, A., Huys, G., Vancanneyt, M. Vandamme, P., De Vuyst, L. (2007) Population dynamics and metabolite target analysis of lactic acid bacteria during laboratory fermentations of wheat and spelt sourdoughs. Appl. Environ. Microbiol. 73, 4741-4750.

[76] Wacher, C., Canas, A., Cook, P.E., Barzana, E., Owens, J.E. (1993) Sources of microorganisms in pozol, a traditional Mexican fermented maize dough. World J. Microbiol. Biotechnol. 9, 269-274. 